pursued with unceasing and absolute integrity. His particular contribution was in psychoanalysis and its application to family and institutional processes. Classical psychoanalysis never very easily lent itself to an application to interpersonal processes but with the development of the Object Relations approach by Klein and her successors, especially Wilfred Bion (who also worked at the Tavistock Clinic), it became possible to identify group processes and their relationship to primitive mental states. He made use of another source of thinking from the Tavistock Centre namely, the work of A.K. Rice, Eric Miller and others on institutional processes. He, together with his colleagues in the adolescent department, used these ideas very creatively and originally in relation to family processes. What is especially sad is that because of his failing health and untimely death, and his tendency to delay when it came to publishing, we are deprived of the fruits of his labours. It will have to be left to others to complete his work.

In the mid ' 80 s he was asked to teach psychoanalytic psychotherapy and later in family therapy at the University of San Pablo, Madrid, and this gradually developed into a major commitment of lecturing and supervising in these subjects.

He earned great respect and affection from his Spanish colleagues and his commitment to them was so great that when ill health forced his retirement from the Tavistock Clinic he continued his work in Spain with even greater intensity as though it was too important to allow any to let up.

Jorge had many friends and admirers. He was very cultured and had a wide knowledge of literature, especially English and Spanish. He was a very kind and warmhearted man and gentle with those who felt vulnerable. He was also a very private person and even those who were his close friends often felt there was much that he kept from them. However, there was a feeling of not quite having brought to fruition the efforts of his intelligence and hard work. He leaves behind patients and students as well as colleagues who feel the richer for having known him. He is survived by his widow Di and his three children from his first marriage.

ROBIN ANDERSON

\title{
Lundbeck Teaching Fellowship
}

Fellows and Members of the Royal College of Psychiatrists, working overseas, are invited to apply for a Teaching Fellow from the UK to come to their country to provide a course of teaching in a designated specialist psychiatric subject. Overseas Fellows and Members may suggest a named teacher, but more importance will be given to the topic of their choice than to any individual.

A sum of $£ 5,000$ per year has been provided by Lundbeck Limited to cover the travel, living and incidental expenses of the Teaching Fellow who, it is envisaged, will complete the course over a period of two to four weeks. The host centre overseas will not be expected to provide any financial support.

Applications for 1995 should be sent to the Dean. The Royal College of Psychiatrists, 17 Belgrave Square, London SWIX 8PG by 30 April 1995. The Teaching Fellow will be selected by the Overseas Liaison Committee.

Professor JoHN Cox

Dean

\section{Residential meeting for psychiatric traineөs}

A residential meeting for psychiatric trainees will be held at Cirencester Agricultural College on 6 and 7 April 1995. It will comprise a series of half day and one day workshops, a presentation from the CTC and a conference dinner. Many workshops will be suitable for both junior and senior trainees and will include Presentation Skills, Research Methodology, Ethics in Psychiatry,
Survival in the NHS, Presentation Graphics and Writing Scientific Papers. Others are aimed primarlly at junior trainees (e.g. How to Obtain an SR Post) or senior trainees (e.g. Managing Your First Day as a Consultant). Further information is available from Suzanna Goodwyn, Department of Postgraduate Education at the College. 